\title{
A Case of Metastatic Hepatocellular Carcinoma Mimicking Acute Cervical Lymphadenitis
}

\author{
Yoon Seok Choi ${ }^{1}$, Chang Hoon Bae ${ }^{1}$, Yong-Dae Kim ${ }^{1,2}$, and Si-Youn Song ${ }^{1}$ \\ ${ }^{1}$ Department of Otorhinolaryngology-Head and Neck Surgery, College of Medicine, Yeungnam University, Daegu; and \\ ${ }^{2}$ Regional Center for Respiratory Diseases, Yeungnam University Medical Center, Daegu, Korea
}

\section{급성 경부 림프절염으로 오인된 전이성 간세포암 1 예}

최윤석 ${ }^{1} \cdot$ 배창훈 $^{1} \cdot$ 김용대 ${ }^{1,2} \cdot$ 송시연 ${ }^{1}$

영남대학교 의과대학 이비인후-두경부외과학교실, ${ }^{1}$ 영남대학교병원 권역 호흡기 전문질환센터 ${ }^{2}$

\author{
Received February 4, 2016 \\ Revised March 22, 2016 \\ Accepted March 23, 2016 \\ Address for correspondence \\ Si-Youn Song, MD, PhD \\ Department of Otorhinolaryngology- \\ Head and Neck Surgery, \\ College of Medicine, \\ Yeungnam University, \\ 170 Hyeonchung-ro, Nam-gu, \\ Daegu 42415, Korea \\ Tel $+82-53-620-3782$ \\ Fax $+82-53-628-7884$ \\ E-mail ssykhs@ynu.ac.kr
}

Hepatocellular carcinoma (HCC) is the most common cancer of the liver and the fifth most common cancer worldwide. The sites of extrahepatic metastasis are usually the lungs, adrenal gland, bone and brain via hematogeneous spreads. The lymphatic spread of HCC, mostly occurring at the regional abdominal lymph nodes, is relatively rare. Cervical lymph node metastasis of HCC is a very rare presentation, so that it is easily neglected in the clinic. In some cases, differential diagnosis between cervical lymphadenitis and lymph node metastasis can be challenging due to similar clinical features such as rapidly growing pattern, tenderness, fever and general ache. We report a case of left cervical lymphadenopathy diagnosed as HCC without prior diagnosis of HCC. A core-needle biopsy of left cervical lymphadenopathy demonstrated poorly differentiated unknown primary metastatic cancer. Positron emission tomography-computed tomography revealed the liver as the primary site of metastasis and the pathologic examination of liver biopsy specimen determined it to be HCC.

Korean J Otorhinolaryngol-Head Neck Surg 2017;60(7):356-9

Key Words Acute lymphadenitis - Cervical lymph node metastasis ·

Hepatocellular carcinoma.

\section{서 론}

간세포암은 간에서 발생하는 가장 흔한 악성 종양으로서, 전 세계적으로 다섯 번째로 흔한 암이며, 암 사망 원인 중 세 번째를 차지한다. ${ }^{1)}$ 간세포암의 원격 전이는 대부분 혈행성 전 파를 통해 폐, 부신, 뼈, 뇌, 유방 등에 발생하며, 림프절을 통 한 전이는 상대적으로 적다. ${ }^{2-5)}$ 간세포암의 림프절 전이는 주 로 인접 림프절을 통해 이루어지는데 드물게 경부 림프절과 같은 원위부 림프절에서도 관찰된다. ${ }^{4,5)}$ 그 중에서도 경부 림 프절 전이로 인해 간세포암이 임상적으로 발견되는 경우는 매
우 드물어 현재까지 전 세계적으로 세 개의 증례만이 보고되 어 있다. ${ }^{6-8)}$

저자들은 이전에 간세포암 진단력이 없던 52세 남자 환자 가 급격하게 커지는 좌측 경부 종물과 통증, 전신 발열 증상 을 주소로 내원하여 급성 화농성 림프절염 의심 하에 치료를 하던 중 임상적 경과의 호전이 없어 시행한 조직 검사에서 원 발 부위를 알 수 없는 저분화 악성 종양 소견을 보여, 양전자 컴퓨터단층촬영(positron emission tomography-computed tomography, PET-CT) 시행 후 간세포암으로 진단된 사례 를 경험하였기에 보고하는 바이다.

This is an Open Access article distributed under the terms of the Creative Commons Attribution Non-Commercial License (http://creativecommons.org/licenses/by-nc/4.0) which permits unrestricted non-commercial use, distribution, and reproduction in any medium, provided the original work is properly cited. 


\section{증 례}

52세 남자 환자가 2주간의 좌측 경부 종물과 통증, 전신쇠 약, 열감을 주소로 내원하였다. 병력청취 상 환자는 이전부터 목과 어깨의 통증을 자주 호소하였고, 내원 2주 전 개인의원에 서 경추와 어깨 관절 부위에 초음파 유도 하 스테로이드 주 사를 맞은 과거력이 있었으며, 시술 이후 상기 증상이 갑자기 발생하였다고 하였다. 과거력 상 고혈압과 당뇨로 약물 투여 중이었으며, B형 간염 바이러스 보균자였으나 이와 관련하여 치료받은 적은 없었다. 30 갑년의 흡연력과 월 10 회, 소주 1 병 정도의 음주력이 있었다. 신체검사 상 좌측 측경부와 쇄골상 부 전반에 걸쳐 최대 직경 $4 \mathrm{~cm}$ 가량의 다발성 압통성 종괴가 비교적 단단하게 촉지되었으며, 그 외의 신체검사 상 특이소 견은 없었다. 황달이나 결막 창백, 하지 부종 등의 만성 간질 환 의심 소견은 관찰되지 않았다. 입원 당시 체온 $38.1^{\circ} \mathrm{C}$, 맥 박 95회 측정되었으며, 그 이외의 활력 징후는 정상 범위였 다. 경부 전산화단층촬영상 좌측 경부 level II-V에 걸쳐 직 경 $1 \sim 4 \mathrm{~cm}$ 가량의 다양한 크기와 불규칙적인 모양의 중심부 괴사를 동반한 다발성 림프절 비대가 관찰되었다(Fig. 1). 입 원 당시 일반 혈액 검사에서 백혈구 증가나 혈소판 감소증은 관찰되지 않았으며(leukocyte: 9.85 K/uL, hemoglobin: 11 $\mathrm{g} / \mathrm{dL}$, platelet: $188 \mathrm{~K} / \mathrm{uL}$ ), 간 기능 검사 상 정상 범위를 보였 고(aspartate aminotransferase: 28 IU/L, alanine aminotransferase: $15 \mathrm{IU} / \mathrm{L}$, total bilirubin: $0.56 \mathrm{mg} / \mathrm{dL}$, direct bilirubin: $0.25 \mathrm{mg} / \mathrm{dL}$ ), 급성기 반응 물질이 정상 범위보다 상승 된 소견이 관찰되었다(erythrocyte sedimentation rate: 82

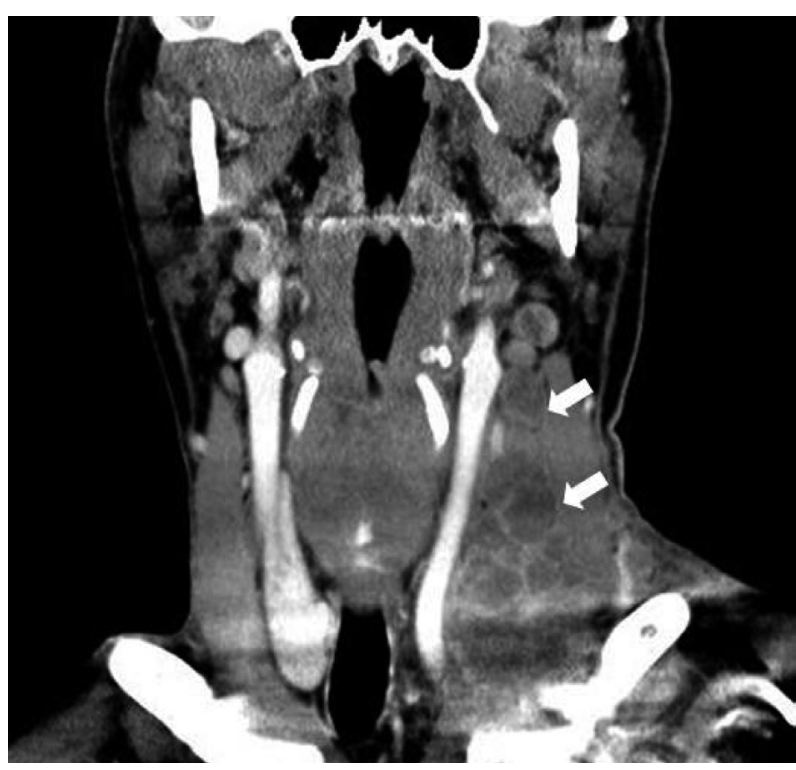

Fig. 1. Neck CT contrast scan shows the multiple conglomerated heterogeneous masses (white arrows) at the left cervical level II-V. $\mathrm{mm} / \mathrm{H}, \mathrm{c}-$ reactive protein: $2.56 \mathrm{mg} / \mathrm{dL}$ ).

환자 병력청취 상 경추와 어깨 관절 부위에 스테로이드 주 사를 맞은 후에 급격히 커진 압통성 종물이라는 점과 전신 발 열의 동반, 급성기 반응 수치의 증가 등을 종합하였을 때 우선 적으로 급성 화농성 경부 림프절염을 의심하여 3세대 cephalosporine계와 clindamycin계 정맥 항생제를 투여하였다. 4 일간의 정맥 항생제 치료 동안 활력 징후는 정상 범위를 유 지하였으나, 경부 종물의 크기와 압통이 호전되지 않아, 초음 파 유도 하 경부 림프절 조직 침생검(ultrasound guided core
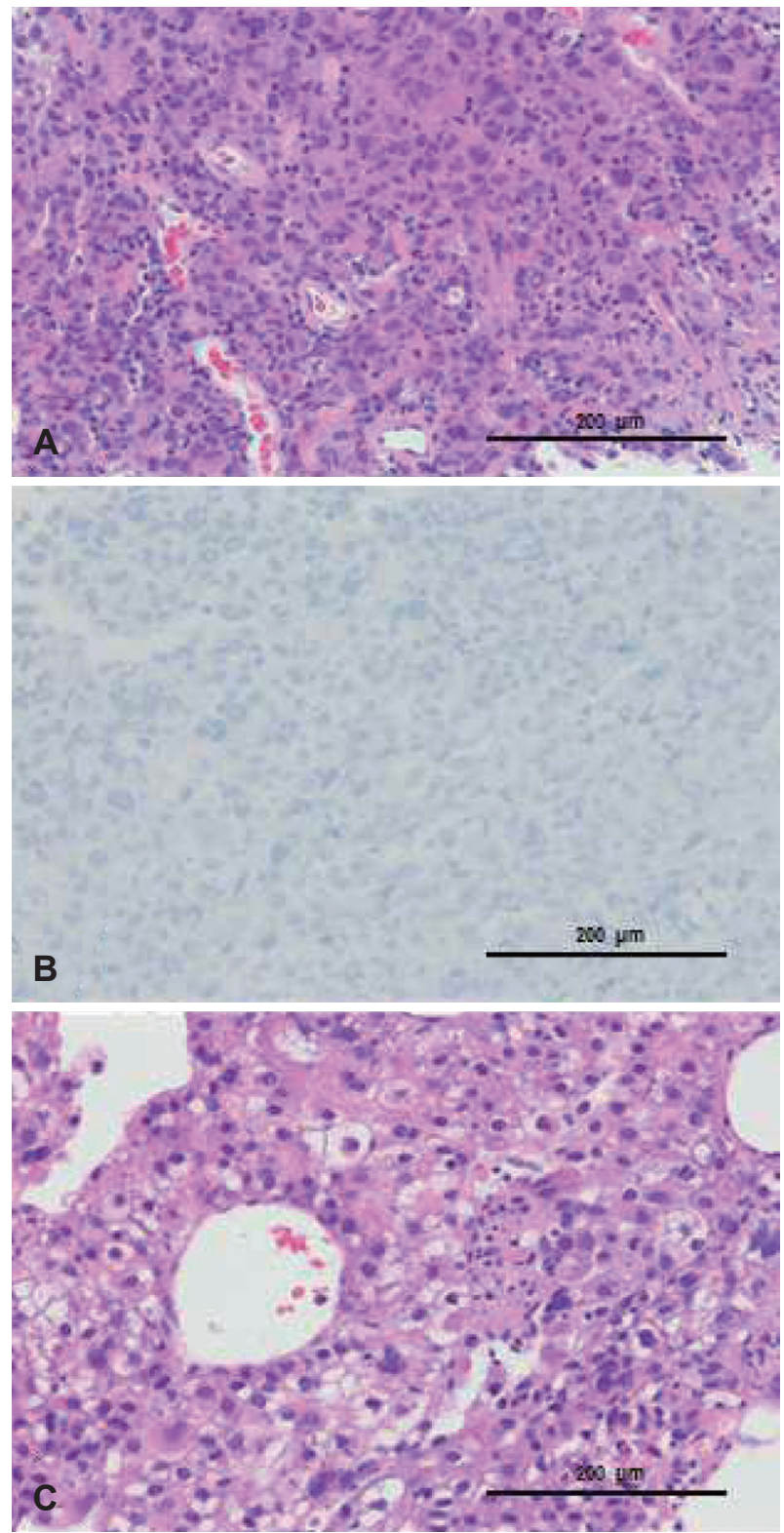

Fig. 2. The pathologic findings of the cervical lymph node show the highly pleomorphic tumor cells (hematoxylin and eosin stain, $\times 200)(A)$, and the negativity on hepatocyte specific antigen $($ HepPar-1) stain $(\times 200)(B)$. The pathologic findings of the liver shows the arranged trabecular pattern of clear cell carcinoma (hematoxylin and eosin stain, $\times 200)(C)$. 
biopsy)을 시행하였다. 병리조직 검사 결과 상 저분화 악성 종 양 소견이 확인되었으나(Fig. 2A), hepatocyte specific antigen(HepPar-1) 면역조직염색을 포함한 여타 특수 염색에서 음 성 소견을 보여 정확한 원발 부위를 알 수 없었다(Fig. 2B). 따라서 종양의 분포와 원발 부위 탐색을 위해 양전자 컴퓨터 단층촬영 $(\mathrm{PET}-\mathrm{CT})$ 을 시행하였다. 양전자 컴퓨터단층촬영 검 사 상 간 우상엽 횡경막 직하부(hepatic dome of right upper lobe)에 중심부 괴사를 동반한 ${ }^{18} \mathrm{~F}$-fluorodeoxyglucose (FDG) 흡수가 증가된 병변이 관찰되었으며, 경부 림프절 이외에 횡 경막 아래와 담낭 주위, 종격동 대동맥 주위, 복부 대동맥 주 위, 좌측 간동맥 주위 림프절에도 ${ }^{18} \mathrm{~F}-\mathrm{FDG}$ 흡수가 증가된 소견이 관찰되었다(Fig. 3). 이후 환자는 소화기 내과로 전과되 어 간 세침 흡인 조직검사 시행 후 간세포암으로 확진 되었으 며(Fig. 2C), 경구 항암제(sorafenib) 치료를 시작하였으나 점 차 악화되는 전신쇠약으로 두 달 후 사망하였다.

\section{고 찰}

간세포암 환자의 사체 부검 연구 결과를 보면, 대략 25 40\% 정도의 간세포암 환자에서 림프절 전이가 동반되어 있는 것 으로 알려져 있다. ${ }^{4)}$ 하지만 임상적으로 발견되는 간세포암의 림프절 전이는 이보다 드물고, 대부분은 간 주위 림프절과 대동맥 주위 림프절 등에서 발견되며, 종격동과 액와 림프절, 경부 림프절과 같은 원위부 전이는 매우 드물다. ${ }^{2-5)}$ 일반적으 로 림프절 전이가 있는 간세포암은 세포 분화도가 낮은 경향 이 있으며, 예후가 나쁜 것으로 알려져 있고, 특히 원위부 림
프절 전이가 동반된 경우는 발견 당시 임상적 병기가 높고, 암 종이 조직학적으로 저분화도를 가질 가능성이 높아 더욱 예 후가 나쁘다. ${ }^{4,9,10)}$

간세포암에서 원발 림프절 전이가 드문 이유는 간의 림프 경로와 관련이 있다. 간의 림프 경로는 위치에 따라 크게 간문 맥 림프관(portal lymphatic vessles), 소엽하 림프관(sublobular lymphatic vessles), 표재성 림프관(superficial lymphatic vessles)으로 나누어 볼 수 있으며, $80 \%$ 이상의 간 림프액은 대부분은 간문맥 림프관을 통해 배액되며, 나머지는 소엽하 림프관과 표재성 림프관을 통해 배액된다. ${ }^{11)}$ 대부분의 림프 액은 간문부(hepatic hilum) 림프절을 통해 복강 내 인접 림 프절로 배액되나, 일부는 소엽하 림프관과 표재성 림프관을 통 해 하대정맥(inferior vena cava) 또는 횡경막을 따라 흥강 내 림프절과 경부 림프절까지 연결되어 있어 간세포암의 원발 림 프절 전이의 주요 경로로 생각된다. ${ }^{11-13)}$

이러한 간의 림프 경로를 보면 간세포암의 발생 위치가 간 세포암의 원발 림프절 전이에 영향을 미칠 것으로 생각되는 데, Watanabe 등니이 시행한 간세포암 환자의 사체 부검 연구 에 따르면, 림프절 전이가 있는 간세포암 환자 중에서 우상엽 에서 발생한 간세포암은 드문 확률로 경부 림프절 전이가 발 견되었으나, 우하엽에서 발생한 암은 경부 림프절 전이를 보 이지 않았다. 본 증례에서도 간세포암은 횡경막 직하부 우상 엽에서 발생하였으며, 이러한 위치가 표재성 림프 경로를 통 해 좌측 경부 림프절 전이가 발생하는 데 영향을 미쳤을 것으 로 생각된다.

분화도가 낮은 경부 림프절 전이암은 급격히 성장하면서
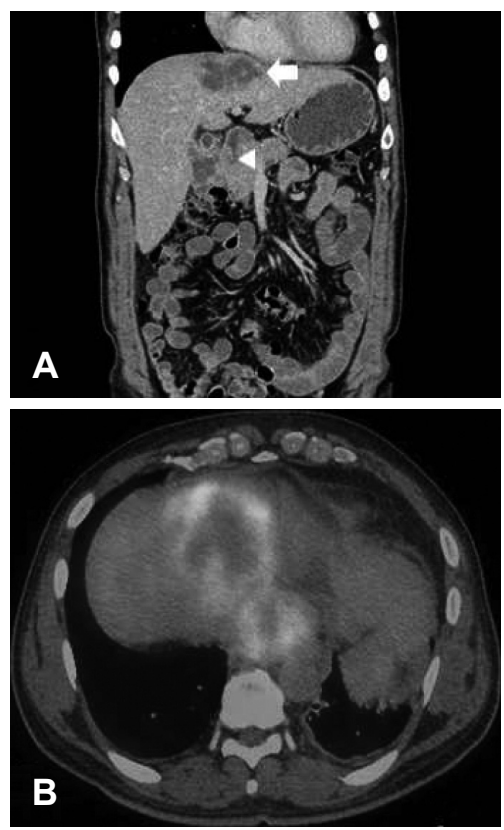
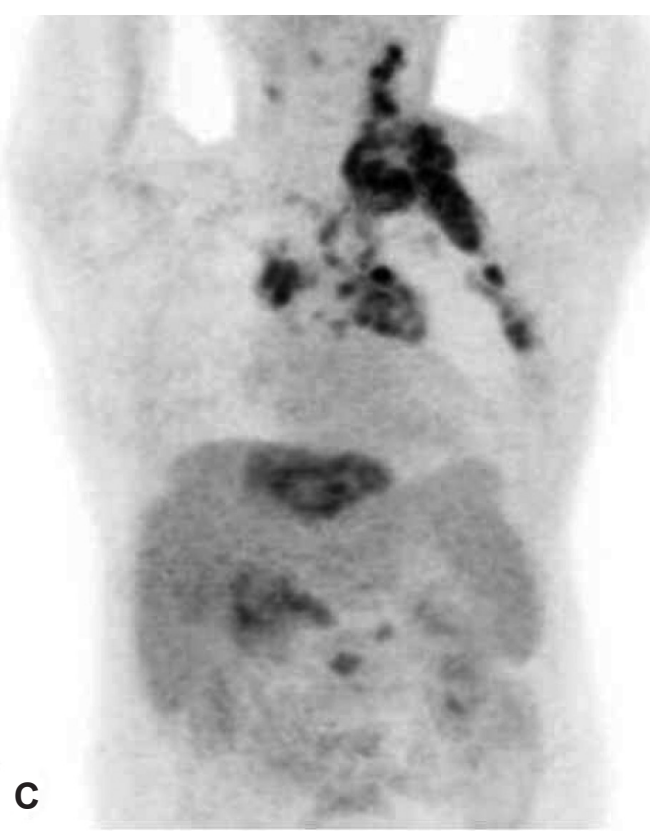

Fig. 3. Abdominal CT scan shows about $6.5 \times 4.4 \mathrm{~cm}$ sized ill-defined mass with the heterogeneous central low density (white arrow) in the right upper lobe of the liver, and the enlargement of paraaortic and pericholecystic lymph nodes (white arrowhead) (A). PET-CT scan shows the uptakes of ${ }^{18} \mathrm{~F}-\mathrm{FDG}$ at the hepatic dome of the liver and inferior phrenic station with central ${ }^{18} \mathrm{~F}-\mathrm{FDG}$ defected area (B). PET-CT scan shows the uptakes of ${ }^{18} \mathrm{~F}-\mathrm{FDG}$ of the multiple lymph nodes at the left cervical level II-V, left axilla, pericholecystic area, and paraaortic area of the mediastinum and abdomen (C). FDG: fluorodeoxyglucose, PET-CT: positron emission tomography-computed tomography. 
압통과 암성 열(cancer fever), 급성 반응기 수치의 증가 등을 동반할 수 있다. 따라서 환자의 병력청취와 임상적 소견만으 로 경부 림프절염과 경부 림프절 전이를 명확히 감별하기 어 려울 수 있다. 이러한 경우 반드시 빠른 조직검사를 시행해 야 한다. 그러나 세침 흡인 조직검사(fine needle aspiration biopsy)에서는 부적절한 검체와 부정확한 흡인 부위, 잘못된 세포 도말 등으로 인한 위음성 가능성을 반드시 염두에 두 어야 하며, ${ }^{14)}$ 이러한 가능성을 줄이기 위해 초음파 유도 하 침 생검을 우선적으로 고려해 볼 수 있다. 또한, 분화도가 낮은 전이암의 경우 특수면역조직화학검사 상에서 원발암과 일치 하지 않는 결과를 보일 수 있다. ${ }^{15)}$ 따라서 본 증례와 같이 조 직 검사 후에도 원발 부위를 명확히 알 수 없을 경우 양전자 컴퓨터단층촬영을 고려하여 원발 부위와 암의 진행 정도를 보다 정확하고 빠르게 파악할 필요가 있겠다.

경부 림프절 전이가 있는 간세포암 환자의 경우 발견 당시 높은 병기를 가지며 분화도가 낮은 암일 가능성이 높기 때문 에 빠른 진단이 반드시 좋은 예후로 연결되지는 않지만, 환 자 상태가 급속히 악화될 수 있으므로 불필요한 치료를 줄 이는 것이 중요하다. 따라서 급격히 커진 광범위한 경부 종물 환자에서 항상 저분화 악성 종양의 가능성을 염두에 두어야 하며, 세심한 신체검사와 함께 빠른 병리조직학적 검사와 영 상학적 검사가 필요하다.

\section{REFERENCES}

1) Sherman M. Hepatocellular carcinoma: epidemiology, surveillance, and diagnosis. Semin Liver Dis 2010;30(1):3-16.

2) Natsuizaka M, Omura T, Akaike T, Kuwata Y, Yamazaki K, Sato T, et al. Clinical features of hepatocellular carcinoma with extrahepatic metastases. J Gastroenterol Hepatol 2005;20(11):1781-7.

3) Yuki K, Hirohashi S, Sakamoto M, Kanai T, Shimosato Y. Growth and spread of hepatocellular carcinoma. A review of 240 consecutive autopsy cases. Cancer 1990;66(10):2174-9.

4) Watanabe J, Nakashima O, Kojiro M. Clinicopathologic study on lymph node metastasis of hepatocellular carcinoma: a retrospective study of 660 consecutive autopsy cases. Jpn J Clin Oncol 1994;24(1): $37-41$.

5) Köklü S, Arhan M, Küksal A, Ulker A, Temuüin T. An unusual presentation of hepatocellular carcinoma. Int J Gastrointest Cancer 2003;34(2-3):63-5.

6) Kobayashi K, Himoto T, Tani J, Miyoshi H, Yoneyama H, Deguchi A, et al. A rare case of hepatocellular carcinoma accompanied by metastasis of a cervical lymph node. Intern Med 2012;51(4):381-5.

7) Madabhavi I, Patel A, Choudhary M, Anand A, Panchal H, Parikh S. Right cervical lymphadenopathy: a rare presentation of metastatic hepatocellular carcinoma. Gastroenterol Hepatol Bed Bench 2014; 7(3):177-82.

8) Lau KK, Wong KW, Ho WC, Lai TS, Lee KC, Leung TW. Hepatocellular carcinoma presenting with right supraclavicular lymph node metastasis and superior mediastinal syndrome. Liver 2000;20(2):184-5.

9) Abe T, Furuse J, Yoshino M, Kinoshita T, Konishi M, Inoue K, et al. Clinical characteristics of hepatocellular carcinoma with an extensive lymph node metastasis at diagnosis. Am J Clin Oncol 2002;25(3): 318-23.

10) Sun HC, Zhuang PY, Qin LX, Ye QH, Wang L, Ren N, et al. Incidence and prognostic values of lymph node metastasis in operable hepatocellular carcinoma and evaluation of routine complete lymphadenectomy. J Surg Oncol 2007;96(1):37-45.

11) Ohtani O, Ohtani Y. Lymph circulation in the liver. Anat Rec (Hoboken) 2008;291(6):643-52.

12) Utsumi M, Matsuda H, Sadamori H, Shinoura S, Umeda Y, Yoshida $\mathrm{R}$, et al. Resection of metachronous lymph node metastases from hepatocellular carcinoma after hepatectomy: report of four cases. Acta Med Okayama 2012;66(2):177-82.

13) Magari S. Hepatic lymphatic system: structure and function. J Gastroenterol Hepatol 1990;5(1):82-93.

14) Stanley MW. Selected problems in fine needle aspiration of head and neck masses. Mod Pathol 2002;15(3):342-50.

15) Kakar S, Gown AM, Goodman ZD, Ferrell LD. Best practices in diagnostic immunohistochemistry: hepatocellular carcinoma versus metastatic neoplasms. Arch Pathol Lab Med 2007;131(11):1648-54. 